\title{
The Determinants of Voting Behaviour: Evidences from the 2015 Elections in Oyo State, Nigeria
}

\author{
Christiana O. Ogbogu, Jesutola A. Olaoye \\ Department of Public Administration \\ ObafemiAwolowo University, \\ Ile-Ife, Nigeria. \\ E-mail: tinaogbogu@yahoo.com
}

Received: January 25, 2017 Accepted: February 18, 2017 Published: April 11, 2017

doi:10.5296/jpag.v7i2.11063 URL: http://dx.doi.org/10.5296/jpag.v7i2.11063

\begin{abstract}
This study identified the determinants of voting behavior of electorates in the year 2015 general election in Oyo State, Nigeria. This was done with a view to ascertain whether gender, age and personal ideology affected the voting behavior of the electorates in the election process. The study which is a survey generated its primary data through the administration of questionnaire on 640 randomly selected electorates from 3 randomly selected local government in Oyo State, Nigeria. The retrieved data were analysed using descriptive and inferential statistics in the form of means, standard deviation, $t$-test and multiple regression. The results revealed that age $(\beta=0.158 ; \mathrm{t}=4.051 ; \mathrm{P}<0.05)$ and personal ideology $(-0.135 ; \mathrm{t}=-3.472 ; \mathrm{P}<0.05)$ significantly predicted electorates' voting behavior, while gender $(\beta=0.068 ; \mathrm{t}=1.748, \mathrm{P}>0.05)$ did not directly predict the voting behavior of the electorates. This implied that there was no significant difference between the voting behavior of the male and female electorates $(\mathrm{t}=-1.488 ; \mathrm{P}>0.05)$. The study concluded that the Nigerian government needs to harness efforts in educating her citizenry on the essence of voting as a civic duty which should not be affected by age, or gender. This would improve the personal ideology of the electorates to the level that guarantees sustenance of democracy.
\end{abstract}

Keywords: Voting behaviour, 2015 elections, Oyo State, Nigeria. 


\section{Introduction}

Elections and voting are an indispensable part of any democratic political system because it is a process through which people are elected into various offices and for different assignments. Voting is the action of formally indicating one's choice of candidate or political party at an election (Erdmann, 2004); while voting behavior is an act of aggregating individual preferences into collective decision in an election (Linberg and Morrison, 2007). Bartel's (2008) analysis of voting behavior focuses on the determinants of why people vote as they do and how they arrive at the decisions they make. This implies that the behavior of a voter is influenced by several factors. Banski et al (2012) for instance, identified a combination of attitudinal, social and psychological factors as responsible for determining individuals' voting behavior. According to Bartel (2008), people vote according to their original political disposition, while some others vote because of the candidates' personal characteristics, qualities and abilities. Furthermore, Lindberg and Morrison (2007) opined that in order to reproduce their leadership, the patron-clientelistic networks of patronage and personal loyalty shaped the behavior of voters in most African political systems. This may be attributed to the change in the dates for the 2015 Presidential and National assembly elections in Nigeria from $14^{\text {th }}$ February and $28^{\text {th }}$ February to $28^{\text {th }}$ March and $11^{\text {th }}$ April, 2015 respectively (Daily Independent, 2015).

Although Nigerian democracy had in the past been truncated by incessant military incursions but since 1999 it has relatively been steady; with elections conducted to elect political functionaries into public offices. The 2015 election for instance was significant in the history of Nigerian democracy because it was an election year throughout the country, except in few states (Anambra, Bayelsa, Edo, Ekiti, Kogi, Ondo and Osun) where governorship elections were not conducted due to post-election litigations. The 2015 Presidential election results revealed that the All Progressive Congress (APC) had the highest votes of 15, 433, 424 constituting $53.97 \%$ of the total votes cast. The party also won 60 and 225 seats in the Senate and House of Representatives respectively. Peoples' Democratic Party (PDP) had the second highest votes of 12,853,162 and won 49 and 127 seats respectively at Senate and House of Representatives. Other parties such as All Progressive Grand Alliance (APGA) and Labour Party (LP) won very few votes, (INEC, 2015).

The study of voting behavior is one of the fields of political science inquiry; yet it remains an under-researched field in African politics because most of the post-independent states gravitated towards authoritarian regimes from the mid1960s to the early 1990s (Lindberg and Morrison,2007).It should be noted that much of what is known about African politics was produced during this period with the emergence of concepts such as : 'clientelism, neo-patrimonialism, personalism, prebendalism and rentier state.' Consequently, many lessons on voters' behavior and alignments were produced under conditions of limited competition in one-party systems

This study therefore provides an understanding of the concept of voting behavior and ascertains the reasons why people vote. It achieves this by interrogating how gender, age and personal ideology determined electorates voting behavior in the 2015 elections in Oyo state, 
Nigeria.

\section{Literature Review}

Voting behaviour is a form of political behaviour which explains how and why decisions are made by public decision makers. It focuses on why people vote as they do and how they arrive at the decisions they make (Bratton, 2013). Voting behaviour in Africa is predominantly explained by factors such as ethnicity, personal linkages, and clientelism (VandeWalle 2003; Erdmann, 2004 and Posner, 2005).The sociological approach analyzes voters behavior from the perspective of the position the individual occupies within social structures. This implies that decisions at elections are determined by such factors, as gender, age, education affiliation to ethnic groups (Banski, Kowalski and Mazur, 2012). Furthermore, factors such as assessments of certain collective characteristics such as personal qualities, abilities, evaluation of performance, party identification and ideology are also determinants of candidate choice (Lindberg, 2006).

Chressanthis et al. (1991) noted that voters' personal ideology about a candidate's Charisma determined their voting preferences. They found that a combination of voter's personal ideological position and leaders' charisma predicted voter's behaviour. Also the stimuli voters receive from political parties shape voters' ideology and behaviour. Bratton and Van De Walle (1997) refer to this as clientetistic voting based on personal ideology and affective ties of patronage. Lindberg and Morrison (2017) found this to be a common feature in African political systems. The Patron-clientelistic networks of patronage and personal loyalty shaped the personal ideology of voters and the leadership they reproduced. Thus exchanging political support for personalized favours and benefits reproduce pacts of mutual loyalty and voters choose representatives based on how good they are as patrons. In Nigeria, the patronage approach was evident in most states during the 2015 election. Many governorship candidates provided food stuffs and many other items to the people of the state during Christmas and New Year celebration and in exchange for their votes (The Punch, 2004); thus Clapham (1993) and Lewis (1996) affirmed that patron-clientelistic networks characterized the African political systems. Bratton and Van de Walle (1997) further found that evaluating voting rationale based on voters' judgment of the performance of parties or representatives shaped the behaviour of voters during elections.

Evidence of gender gap in electoral behaviour is prominent globally as well as in Nigeria (Ogbogu, 2012). Studlar et al., (1998) examined the male - female differences in voting behaviour in terms of three frequently offered explanations: inequalities in socioeconomic attainment, greater situational constraints on women and differences in political orientations. They found that in Britain and Australia gender inequalities in socio economic attainment and situation constraints such as women's greater familial responsibilities were the discriminatory factors that explain the gender gap and voting behaviour of females. This is not surprising therefore because throughout human history, voting and politics has been closely associated with masculinity. Before now, women's participation in voting and politics in Nigeria had been very low and it was not until 1979 that women in Northern Nigeria were given the franchise to exercise their voting rights (Ogbogu, 2012). Since woman earned the right to 
vote in Nigeria, they have been making a difference in the outcome of the voting process.

Age has been identified as an important factor that determines voting behaviour. Berman and Johnson (2000) found that age explained different attitudes towards voting and that there was age difference in voting behaviour among electorates. Also Balogun and Olapegba (2001) in examining the influence of psychological and demographic variables among voters in Ibadan, Nigeria, found that age was a major predictor of voting behaviour.In the same vein, Riggle and Johnson (1996) found that young people in the United Kingdom are the least likely to vote; rather they are bystanders and most likely not registered to vote. The explanation for this is that they are most likely not to be politically engaged.

Studies (Gill, 2003, Sanbonmatsu, 2002 and Kaufman, 2002) have shown that older people vote at higher rates than people in the younger age groups, and that voter turnout is lowest among young adults.

Gill (2003) explained that the age group differences in voting participation are attributable to life course effects that correspond to changing characteristics, needs and incentives of people as they grow older. He implied that interest in politics increases with age and declines only slightly at advanced old age. He further noted that older people voted more because people have more interest and personal stake in government programmes as they grow older.

Research on voting behaviour suggests that varieties of factors account for voters' choice of a candidate during elections. Although a lot of studies have been carried out on the determinants of voting behaviour, not much work has been done in determining how age, gender and personal ideology determine the voting behaviour of electorates in the 2015 elections in Oyo State, Nigeria, hence this study.

\section{Methodology}

This study adopted a survey research design and was carried out in

the three senatorial districts of Oyo State, Nigeria. The random sampling technique was used in picking one local government from each of the three senatorial districts for the study as follows: Sarki East, Oyo East and Ibadan North Local government areas. Thereafter, the proportionate sampling technique was used in administering questionnaires on 640 electorates from Sarki East (180); Oyo East (210) and Ibadan North (250) local government areas. The questionnaire consisted of 21 items adopted from Moely, Mercer and Hustre's (2002) version of the voting behaviour rating instrument. The retrieved questionnaires were analysed using descriptive statistics (percentages, means and standard deviation) and inferential statistics (multiple regression and t-test).

\section{Results and Discussion}

Table 1: Demographic characteristics of the respondents

\begin{tabular}{lll}
\hline Gender & Frequency & Percentage $(\%)$ \\
\hline
\end{tabular}


Male

Female

Total

Age

$18-25$ years

26.33 years

34 years and above

Total

\section{Marital Status}

Single

Married

Separated/Divorced

Widowed

Total
149
362

278

640

100

114

426

640

100.00

56.6

43.4

100.00

15.6

17.8

66.6
23.3

435

68.0

26

4.1

30

4.7

640

100.00

Results on the demographic variables of the respondents as indicated on Table 1 reveals that more males $(56.6 \%)$ than females $(43.4 \%)$ constituted the population of the study. Data on the age of respondents shows that majority $(66.6 \%)$ of them were above 34 years of age and were married $(68 \%)$.

Table 2: Voting behaviour of respondents by their gender

\begin{tabular}{llllllll}
\hline Gender & Mean & $\begin{array}{c}\text { Standard } \\
\text { deviation }\end{array}$ & $\mathbf{N}$ & Df & $\mathbf{t}$ & P-value & significance \\
\hline Male & 42.95 & 4.77 & 640 & 638 & -1.48 & 0.137 & NS \\
Female & 43.51 & 4.73 & & & & & \\
\hline
\end{tabular}


* P. $>0.05$

Table 2 shows data on the voting behaviour of respondents by their gender. The result shows that there was no significant difference between the voting behaviour of both the male and female electorates $(\mathrm{t}=-1.488, \mathrm{P}<0.05)$. Although gender has been an important factor over the years in the study of voting behavior, this result however has shown that both sexes exercised their voting rights in the 2015 elections held in Oyo State, Nigeria. This is an indication that women are free to exercise their voting rights as well as participate in political activities. This result corroborates that of Balogun and Olapegba (2007), Gill (2003) and Adesina (2010) who affirmed that over seven decades ago women earned the right to vote and have since then in the United States and in Nigeria made a difference in the outcomes of politics and elections. This result also confirms that Nigeria ratified the United Nations Convention on the political rights of women in 1985, which stipulates that women shall have equal terms with men and without any discrimination be entitled to vote in all elections and be eligible for elections in all public elected bodies (Chizea and Njoku, 1991).

Although literature (Sanbonmatsu, 2002; Kaufmann, 2002; and Ogbogu, 2012) has shown that resistance to women in politics remains strong in post-independence Africa but the result of this study supports that of Omoede (2004) who found that the fourth republic which commenced in 1999 has witnessed the emergence of women in Nigerian politics. This outcome confirms the provision made by the 1999 Nigerian constitution which supports the non-discrimination and equal rights for women to participate in politics (BAOBAB, 2003). Furthermore result on Table 2 implies that equitable participation of woman is a fundamental prerequisite for genuine and sustainable democracy and that a higher number of them in government would contribute to stronger attention to women's issues.

Table 3: Voting behaviour of respondents by their age

\begin{tabular}{lllll}
\hline Age & Frequency & $\begin{array}{l}\text { Percentage } \\
(\%)\end{array}$ & Mean & $\begin{array}{l}\text { Standard } \\
\text { Deviation } \\
(\text { SD })\end{array}$ \\
\hline $18-25$ & 100 & 15.6 & 22.8 & 2.23 \\
$26-33$ & 114 & 17.8 & 32.6 & 3.34 \\
34 and above & 426 & 66.5 & 43.7 & 4.90 \\
\hline Total & $\mathbf{6 4 0}$ & $\mathbf{1 0 0}$ & $\mathbf{4 3 . 1 9}$ & $\mathbf{4 . 7 5}$ \\
\hline
\end{tabular}

Result in Table 3 reveals the voting behaviour of respondents by their age. 


\section{Macrothink}

Data on the Table shows that the age of voters impacted on their voting behaviour this is because those in the older age group of 34 years and above recorded the highest percentage $(66.5 \%)$ of people who voted, with a mean score of 43.7. Those within the lower age group (18-25years and 26-33 years) recorded a lower percentage of $15.6 \%$ and $17.8 \%$ respectively. These results uphold the findings of the studies by Riggle and Johnson (1996) and Berman and Johns (2000), who found that younger people in the United Kingdom were the least likely to vote and were less politically engaged. They also found that interest in politics increased with age. In the same vein, Balogun and Olapegba (2007) and Oluwatola and Arogundade (2008) found that some psychosocial factors including age, were prominent in predicting the voting behaviours of Nigerians.

Table 4: Voting behaviour of respondents by their personal ideology

\begin{tabular}{lllllll}
\hline Personal ideology & SA & A & U & D & SD & Mean \\
& $(\%)$ & $(\%)$ & $(\%)$ & $(\%)$ & $(\%)$ & $(\bar{x})$
\end{tabular}

My family has an ideology that guides us in voting during elections.

$\begin{array}{llllll}167 & 290 & 47 & 111 & 25 & 3.72 \\ (26.1) & (45.3) & (7.3) & (17.3) & (3.95) & \end{array}$

I voted for change and for variety, irrespective of a candidate's performance or personal qualities.

$\begin{array}{llllll}161 & 338 & 44 & 71 & 26 & 3.84 \\ (25.2) & (52.8) & (6.9) & (11.1) & (4.1) & \\ & & & & & \\ & & & & & \\ & & & & & \\ 74 & 105 & 91 & 226 & 144 & 3.41 \\ (11.6) & (16.4) & (14.2) & (35.3) & (22.5) & \end{array}$

I am an adherent of a particular party and voted based on preference for that particular party.

Materials and monetary gains from candidates motivated me to vote for them and were major determinants of voting $\begin{array}{lllll}374 & 38 & 56 & 148 & 23 \\ (58.4) & (5.9) & (8.8) & (23.6) & (3.6)\end{array}$ for aspirants. 
I voted based on evaluating the antecedents of candidates as well as their performance and what they hope to

$259296 \quad 50$

$(40.5) \quad(46.3) \quad(7.0)$

$\begin{array}{ll}27 & 8 \\ (4.2) & (1.3)\end{array}$

8

achieve.

Table 4 shows the personal ideologies that predicted the voting behaviours of the respondents. The results revealed that a higher percentage $(58.4 \%)$ of the respondents strongly agreed that material and monetary gains motivated them to vote for aspirants in the elections. This also had the highest mean score of 4.27. Furthermore, data on the table, revealed that "evaluating the antecedents of candidates as well as their performance and what they hope to achieve" was another major (40.5\%) personal ideology that predicted the voting behaviour of the respondents. It had a mean score of 4.20. The other personal ideologies that determined the voting behaviour of the respondents were: Voting for change irrespective of candidate's performance $(\bar{x}=3.72)$, family ideology $(\bar{x}=3.72)$ and being an adherent of a particular

party and voting based on such preference $((\bar{x}=3.41)$. These results corroborate that of Adeolu (2014) who found that electorates preference for immediate gains like food and money also known as "stomach infrastructure" mostly motivated them to vote during the 2014 governorship election in one of the states located in south western Nigeria. He noted that prior to that election, most political parties distributed food items, money, kerosene and various provisions to voters.

Furthermore, result in Table 4 corroborates that of Mullins' (1972) who found that people vote for candidates based on their performance and whom they feel best protects their ideals and country. People are therefore influenced by transformational leaders who are confident, skilled, focused and have good plans for their country.

Generally, results on the table confirm that personal ideology influence the voting behaviour of electorates and determines the reasons for preferring one candidate to the others in an election. This implies that voters' perception and evaluations of the qualities and antecedents of candidates, general assessment of their performance, patronage through the provision of monetary and material gains, desire for change and preference for a particular political party played key role in determining their voting behaviour. In all of the submissions, patronage through the provision of monetary and material gains was distinct in shaping the personal ideologies of the respondents and accounted for their voting pattern. However, it should be noted that the various ideologies that can influence the voting behavior of electorates vary in different regions of the world.

Table 5:Multiple regression of gender, age, personal ideology and respondents' voting 


\section{behaviour}

\begin{tabular}{llllll}
\hline Model & $\begin{array}{l}\text { Unstandardized } \\
\text { coefficients }\end{array}$ & \multicolumn{3}{l}{$\begin{array}{l}\text { Unstandardized } \\
\text { coefficients }\end{array}$} \\
\cline { 2 - 6 } & B & & & \\
& & Std & $\boldsymbol{\beta}$ & $\mathbf{t}$ & Significance \\
& & error & & & \\
\hline Constant) & 41.990 & 1.076 & & 39.027 & 0.000 \\
Gender & 0.654 & 0.374 & 0.068 & 1.748 & 0.810 \\
Age & 1.005 & 0.248 & 0.158 & 4.051 & $0.000^{*}$ \\
Personal Ideology & -0.069 & 0.020 & -0.135 & -3.472 & $0.001 *$ \\
\hline
\end{tabular}

$* \mathrm{P}<0.05$

Data on Table 5 shows the composite effect of gender, age and personal ideology on the voting behaviour of the respondents.

The effect of gender on the respondents' voting behaviour was not significant $(\beta=0.068$; $\mathrm{t}=1.748, \mathrm{P}>0.05)$, while age $(\beta=0.158 ; \mathrm{t}=4.051, \mathrm{P}<0.05)$ and personal ideology $(\beta=-0.135$; $\mathrm{t}=-3.472, \mathrm{p}<0.05)$ were significant. Personal ideology has been identified as a key determining factor of voters' behaviour in the African political systems due to patron-clientelistic networks of patronage. Thus, the result of this study corroborates this assertion which is also in line with Chressanttis's (1991) studies. Age was also found to be a predictor of voters' behaviour. This is not unconnected with the fact that as people advance in age, they develop more interest in politics and have more personal stake in government programmes than when they were younger. The fact that gender did not significantly predict the behaviour of voters indicates that both males and females had equal rights to vote. This is an indication that feminist movements have achieved a great deal in politicizing gender within the nation states and international systems. It is important to view this achievement within justifiable pride as an important success in the new millennium.

\section{Conclusion}

Political participation and voting behaviour serve as critical ingredients in a democracy. This study examined the factors that predicted the voting behaviour of electorates in the 2015 elections in Oyo State, Nigeria. It found that age and personal ideology were prominent in determining the voting behaviour of electorates, while gender did not. This confirmed the fact that older people develop more interest in politics than the younger ones. In addition, voters' 
ideology about a candidate's charisma as well as patron-clientelistic networks of patronage influences voting behaviour. These factors have provided an explanation for the voting behavior of electorates in the 2015 elections in Oyo State as well as an understanding of electoral dynamics. In view of these, this study recommends the need for the Nigerian government to harness more efforts in educating her citizenry on the importance of voting irrespective of age or sex, as well as eradicate voters' personal ideology of dependence on patron-clientelistic network in voting for candidates during elections.

\section{References}

Adeolu, D. (2016). Voting behaviour in Osun 2014 governorship election in Nigeria. Public Policy and Administration Research. Vol. 4 (8), pp.1-10.

Balogun,S., and Olapegba, P. (2007). Majority carry the vote: Psycho Demographic influence on voting behaviour. Studies in Tribes Tribals. Vol. 5(1), pp. 5-7.

Banski, T., Kowalski, M. and Mazur, M. (2012): Spatial differences in voting behaviour among inhabitants of rural Poland, as exemplified by parliamentary elections in the period 1993-2007. Geographical JournalVol. 64 (2), pp.91-109.

Bartels, L. (2008). The study of electoral behavior, in Jan. E. Leighley (ed). The oxford Handbook of American elections and Political behaviour. United Kingdom: Oxford University Press.

BAOBAB (2003). Political rights and responsibilities of women and citizens. BAOBAB for Woman's Human Rights Legal Literacy Series 4. Lagos: BAOBAB for women's human rights

Bates, R. (1981). Markets and States in Tropical Africa. Berkely: University of California Press.

Bratton, M. and Van de Walls, N. (1997): Democratic Experiments in Africa Regime Transitions in a Comparative Perspective. Cambridge: Cambridge University Press.

Berman, D., and Johnson, . R (2000); Age, ambition and the local charter: A study in voting. Social Science Journal. Vol. 37(1), pp. 19-26.

Chizea, D. and Njoku, J. (1991). Nigerian Women and the Challenges of our time. Lagos: Malthouse.

Clapham, C. (1993). Democratization in Africa: obstacles and Prospects.Third quarterly. Vol. 4 (3), pp 423-38.

Chressanthis, G., Gilbert, K. and Grima, P. (1991). Ideology, constituent interests and senatorial voting. The case of abortion. Social Science Quarterly, Vol. 72(3), pp. 588-600.

Daily Independent (2015). INEC and the postponed elections. Available fromhttp://dailyindependentnig.com/2015/02inec-postponed-elections. Accessed on 28th April, 2015. 


\section{I Macrothink}

Journal of Public Administration and Governance

ISSN 2161-7104

2017, Vol. 7, No. 2

Erdman, G. (2004): Party research: The Western European bias and the African Labyrinth: Democratization. Vol. 11(3), pp. 63-87.

Gill, S. (2003). Gender and voting preferences in Japanese Lower House Elections. Japanese Journal of Political Science. vol. 4(1), pp. 1-39.

Independent National Electoral Commission (2015): The postponed election. Available from: www.inecnigeria.org. Accessed on $28^{\text {th }}$ April, 2015.

Jackson, R. and Rosberg, C. (1982): Personal rule in Black Africa. Berkely and Los Angeles: University of California Press.

Jean-Francois, M. (1982). "The underdeveloped state in tropical Africa. Political clientelism or neo-patrimonialism?" In Clapham, C. (ed.). Private Patronage and Public Power: Political Clientelism in the Modern State. London, Frances Pinter

Joseph, R. (1987). Prebendalism and Democracy in Nigeria. Cambridge: Cambridge University Press.

Johnson, R. and Pattie, C. (2000): Inconsistent attitudes within consistent attitudinal structures: comments on an important issue raised by John Bartle's paper on causal modelling of voting in Britain. British Journal of Political Science. Vol. 3(2), pp.301-374.

Kaufman, K.M. (2002): Culture wars, secular realignment and the gender gap in party identification. Political Behaviour. Vol. 24(3), pp. 283-307.

Lewis, P.M. (1996): Economic reform and political transition in Africa. The quest for a politics of development. World politics. Vol. 49(1), pp.92-129.

Lemarchand, R. (1972). Political clientelism and ethnicity in tropical Africa: Competing Solidarities in Nation - building. American Political Science Review. Vol. 66(1)pp.68-90.

Lindberg, S. (2006). Democracy and elections in Africa. Baltimore: John Hopkins University Press.

Lindberg, S. and Morrison, M.K. (2007). Are African voters really ethnic or clientelistic? Survey evidence from Ghana. Political Science Quarterly. Vol. 9(2). pp.25-36.

Mullins, W.(1992). On the concept of ideology in political science. The American Political Science Review. Vol. 97(3). Pp. 255-375.

Ogbogu, C.O. (2012). The role of women in politics and in the sustenance of democracy in Nigeria. International Journal of Business and Social Science. Vol. 3 (18), pp. 182-191.

Posner, D. (2005): Institutions and Ethnic Politics in Africa. Cambridge: University Press.

Riggle, E. and Johnson, M. (1996). Age difference in political decision-making: strategies for evaluating political candidates. Journal of Political Behaviour. Vol. 8(1), pp. 43-54.

Sanbonmatsu, K. (2002). Gender stereotypes and vote choice. American Journal of Political Science. Vol. 46(1), pp.20-34. 


\section{Macrothink}

Sklar, C. (1983). Democracy in Africa. African Studies Review. Vol. 26(3), pp. 11-24.

Studlar, D., Mcallister, L. and Hayes, B. (1998): Explaining the Gender gap in voting: A cross-national analysis. Social Science Quarterly. Vol. 79(4), pp. 779-798.

The Punch (2014). Election: Stomach infrastructure spreads. Available from http://www.punchng.com/politics/election-stomach-infrastructure-spreads-to-osun. Accessed on $28^{\text {th }}$ April, 2015.

Van de Walle, N. (2003): Presidentialism and clientelism in Africa's Emerging Party Systems. Journal of Modern African Studies. Vol. 41(2), pp. 297-321.

\section{Copyright Disclaimer}

Copyright for this article is retained by the author(s), with first publication rights granted to the journal.

This is an open-access article distributed under the terms and conditions of the Creative Commons Attribution license (http://creativecommons.org/licenses/by/3.0/). 